\title{
Bibliography
}

Acheson, N. and Milofsky, C. (2008) 'Peace building and participation in Northern Ireland: Local social movements and the policy process since the "Good Friday" Agreement', Ethnopolitics, vol. 7, no. 1, pp. 63-80.

Anderson, J. (1998) 'Integrating Europe, integrating Ireland: The socio-economic dynamics', in J. Anderson and J. Goodman (eds) Dis/agreeing Ireland: Context, Obstacles, Hopes, London: Pluto Press, pp. 73-88.

Arthur, P. (1994) 'The Anglo-Irish Joint Declaration: Towards a lasting peace?, Government and Opposition, vol. 29, no. 2, pp. 218-230.

Arthur, P. (1977) 'Devolution as administrative convenience: A case study of Northern Ireland', Parliamentary Affairs, vol. 30, no. 1, pp. 97-106.

Aughey, A. (2012) 'Northern Ireland narratives of British democracy', Policy Studies, vol. 33 , no. 2, pp. 145-158.

Aughey. A. (2005) The politics of Northern Ireland: Beyond the Belfast Agreement, London: Routledge.

Bache, I. (2012) 'Multi-level governance in the European Union', in D. Levi-Faur (ed.) Oxford Handbook of Governance, Oxford: Oxford University Press, pp. 628-641.

Barry, J. (2009) "It ain't easy being green": Sustainable development between environment and economy in Northern Ireland', Irish Political Studies, vol. 24, no. 1, pp. 45-66.

Bell, V. (2004) 'Spectres of peace: Civic participation in Northern Ireland', Social and Legal Studies, vol. 13, no. 3, pp. 403-428.

Bew, P. and E. Meehan (1994) 'Regions and borders: Controversies in Northern Ireland about the European Union', Journal of European Public Policy, vol. 1, no. 1, pp. 95-113.

Bew, P., P. Gibbon and H. Patterson (1979) The State in Northern Ireland 1921-1972, Manchester: Manchester University Press.

Birnie, E. (2000) 'Trading partners: Northern Ireland's external economic links', in D. Kennedy (ed.) Living with the European Union: The Northern Ireland Experience, London: Macmillan, pp. 94-114.

Birnie, E. and D. Hitchens (2001) 'Chasing the wind? Half a century of economic strategy documents in Northern Ireland', Irish Political Studies, vol. 16, no. 1, pp. 1-27.

Birnie, E. and D. Hitchens (1999) Northern Ireland Economy: Performance, Prospects, Policy, Aldershot: Ashgate.

Birnie, E. and D. Hitchens (1998) 'An economic agenda for the Northern Ireland Assembly', Regional Studies, vol. 32, no. 6, pp. 769-787.

Birrell, D. (2012a) 'Policy copying and public sector reform in Northern Ireland', Regional and Federal Studies, vol. 22, no. 3, pp. 309-321.

Birrell, D. (2012b) 'Intergovernmental relations and political parties in Northern Ireland', British Journal of Politics and International Relations, vol. 14, no. 2, pp. 270-284. 
Birrell, D. (2012c) Comparing Devolved Governance, Basingstoke: Palgrave.

Birrell, D. (2009) Direct Rule and the Governance of Northern Ireland, Manchester: Manchester University Press.

Birrell, D. and A. Murie (1980) Policy and Government in Northern Ireland: Lessons for Devolution, Dublin: Gill and MacMillan.

Bogdanor, V. (1999) Devolution in the United Kingdom, Oxford: Oxford University Press.

Bonner, K. and D. Rea (2009) 'Northern Ireland: Economic facts and statistics', First Trust Bank Economic Outlook and Business Review, vol. 24, no. 2, pp. 45-70.

Borooah, V. K. (1993) 'Northern Ireland - Typology of a regional economy', in P. Teague (ed.) The Economy of Northern Ireland, London: Lawrence and Wishart, pp. 1-23.

Börzel, T. and K. Heard-Lauréote (2009) 'Networks in EU multi-level governance: Concepts and contributions', Journal of Public Policy, vol. 29, no. 2, pp. 135-151.

Boussaguet, L., R. Dehousse and S. Jacquot (2010) 'Change and continuity in European governance', Les Cahiers Européens de Sciences Po, no. 6, Paris: Centre d’Études Européennes at Sciences Po.

Bovens, M. (2007) 'New forms of accountability and EU governance', Comparative European Politics, vol. 5, no. 1, pp. 104-120.

Bradbury, J. and N. McGarvey (2003) 'Devolution: Problems, politics and prospects', Parliamentary Affairs, vol. 56, no. 2, pp. 219-236.

Bradbury, J. and J. Mitchell (2001) 'Devolution: New politics for old?', Parliamentary Affairs, vol. 54, no. 2, pp. 257-275.

British-Irish Council (2012) Communiqué: 17th BIC Summit (Dublin), 13 January.

Buchanan, S. (2008) 'Transforming conflict in Northern Ireland and the border counties: Some lessons from the Peace Programmes on valuing participative democracy', Irish Political Studies, vol. 23, no. 3, pp. 387-409.

Bulmer, S. (1983) 'Domestic politics and European Community decision-making', Journal of Common Market Studies, vol. 21, no. 4, pp. 349-63.

Bulmer, S., M. Burch, P. Hogwood and A. Scott (2006) 'UK devolution and the European Union: A tale of cooperative asymmetry?', Publius: The Journal of Federalism, vol. 36, no. 1, pp. 75-93.

Bulmer, S., M. Burch, C. Carter, P. Hogwood and A. Scott (2002) British Devolution and European Policy-Making, Basingstoke, Palgrave.

Burch, M., R. Gomez, P. Hogwood and A. Scott (2005) 'Devolution, change and European Union policy-making in the UK', Regional Studies, vol. 39, no. 4, pp. 465-475.

Burrows, N. (1999) 'Relations with the European Union', in G. Hasan (ed.) A Guide to the Scottish Parliament, London: The Stationery Office and Centre for Scottish Public Policy, pp. 125-131.

Byrne, S., O. Skarlato, E. Fissuh and C. Irvin (2009a) 'Building trust and goodwill in Northern Ireland and the border counties: The impact of economic aid on the peace process', Irish Political Studies, vol. 24, no. 3, pp. 337-363.

Byrne, S., J. Arnold, E. Fissuh, K. Standish, C. Irvin and P. Tennent (2009b) 'The EU Peace II and the International Fund for Ireland: Nurturing cross-community contact and reconciliation in Northern Ireland', Geopolitics, vol. 14, no. 4, pp. 630-652.

Byrne, S. and C. Irvin (2001) 'Economic aid and policy-making: Building the peace dividend in Northern Ireland', Policy and Politics, vol. 29, no. 4, pp. 413-429.

Cadogan Group (1998) Rough trade: Negotiating a Northern Ireland Settlement Belfast: The Cadogan Group.

Carey, S. (2002) Undivided loyalties: Is national identity an obstacle to European integration?', European Union Politics, vol. 3, no. 4, pp. 387-413. 
Carmichael, P. (2002) 'The Northern Ireland civil service: Characteristics and trends since the 1970s', Public Administration, vol. 80, no. 1, pp. 23-49.

Carmichael, P. (2001) 'The Northern Ireland Civil Service', Public Money and Management, April-June, pp. 33-38.

Carmichael, P. (1999) 'Territorial management in the "New Britain": Towards devolutionplus in Northern Ireland?', Regional and Federal Studies, vol. 9, no. 3, pp. 130-156.

Carmichael, P. and C. Knox (2004) 'Devolution, governance and the peace process', Terrorism and Political Violence, vol. 16, no. 3, pp. 593-621.

Carter, C. (2013) 'Rethinking UK parliamentary adaptation in EU affairs: Devolution and Europeanisation', The Journal of Legislative Studies, vol. 19, no. 3, pp. 392-409.

Clark, G. (1999) 'Scottish devolution and the European Union', Public Law, Autumn, pp. 504-524.

Clements, B. (2010) 'Exploring and explaining public attitudes towards the European integration process in Northern Ireland', Irish Political Studies, vol. 25, no. 3, pp. 393-416.

Coakley, J. (2010) 'Northern Ireland and the British Dimension', in J. Coakley and M. Gallagher (eds) Politics in the Republic of Ireland (5th edition), London: Routledge, pp. 383-406.

Coakley, J. (2009) 'Implementing consociation in Northern Ireland', in R. Taylor (ed.) Consociational theory: McGarry and O'Leary and the Northern Ireland Conflict, London: Routledge, pp. 122-145.

Coakley, J. (2008) 'Has the Northern Ireland problem been solved?', Journal of Democracy, vol. 19 , no. 3, pp. $98-112$.

Coakley, J. (2007) 'National identity in Northern Ireland: Stability or change?', Nations and Nationalism, vol. 13, no. 4, pp. 573-597.

Coakley, J. (2005) 'The North-South relationship: Implementing the agreement', in J. Coakley, B. Laffan and J. Todd (eds) Renovation or Revolution? New Territorial Politics in Ireland and the United Kingdom, Dublin: University College Dublin Press, pp. 110-131.

Coakley, J., B, Ó Caoindealbháin and R. Wilson (2006) 'The operation of the North-South implementation bodies', IBIS Working Paper no. 56.

Coakley, J. and L. O'Dowd (2007) 'The transformation of the Irish border', Political Geography, vol. 26, no. 8, pp. 877-885.

Cochrane, F. (2006) 'Two cheers for the NGOs: Building peace from below in Northern Ireland', in M. Cox, A. Guelke and F. Stephen (eds) A Farewell to Arms? Beyond the Good Friday Agreement (2nd edition), Manchester, Manchester University Press, pp. 253-267.

Commission of the European Communities (1990) Community Support Framework 1989-93 (Objective 1) (Northern Ireland), Luxembourg: Office for Official Publications of the European Communities.

Committee of the Centre (Northern Ireland Assembly) (2002) Inquiry into the Approach of the Northern Ireland Assembly and the Devolved Government on European Issues, Report 02/01R, Belfast: Stationery Office.

Committee for Finance and Personnel (Northern Ireland Assembly) (2000) Inquiry into European Union Structural Funds: The Peace II Programme, Report 3/99/R, Belfast: Stationery Office.

Committee of the Office of the First Minister and Deputy First Minister (Northern Ireland Assembly) (2010) Report on its Inquiry into Consideration of European Issues, Report NIA 33/09/10R, Belfast: Stationery Office.

Connolly, M. and A. Erridge (1990) 'Central government in Northern Ireland', in M. Connolly and S. Loughlin (eds) Public Policy in Northern Ireland: Adoption or Adaptation?, Belfast: Policy Research Institute, Queen's University Belfast and University of 
Ulster, pp. 19-34.

Cowen, B. (2007) Speech by the Tánaiste at the Launch of the Peace III and Interreg IVA Programmes, Stormont Hotel, Belfast, 14 April.

Cronin, S. (1987) Washington's Irish Policy 1916-1986: Independence, Partition and Neutrality, Dublin: Anvil Books.

Darby, J. (ed.) (1976) Conflict in Northern Ireland: The Development of a Polarised Community, Dublin: Gill and MacMillan.

De Stefano. L. (2010) 'Facing the water framework directive challenge: A baseline of stakeholder participation in the European Union', Journal of Environmental Management, vol. 91, no. 6, pp. 1332-1340.

Democratic Dialogue (2000) Structurally Unsound: The Northern Ireland Bids for Further EU Monies, Briefing Paper, Belfast: Democratic Dialogue.

Department for Business, Innovation and Skills (BIS) (2011) UK Government Response: European Commission Consultation on the Single Market Act (February) London: Department for Business, Innovation and Skills.

Department of Agriculture and Rural Development (DARD) (2011) Consultation on EU Commission Proposals for Common Agricultural Policy (CAP) Reform Post 2013 (November) Belfast: Department of Agriculture and Rural Development (NI).

Department of Agriculture and Rural Development (DARD) (2001) Vision for the Future of the Agri-Food Industry, Report of the Vision Group, 4 October.

Department of Education and Learning (DEL) (2007) Minister on fact-finding visit to Brussels, Press release, 13 June, available at: http://goo.gl/1m4BmU, accessed 8 August 2013.

Department of Finance and Personnel (DFP) (2012) Northern Ireland and Europe in Partnership: Preparing for the 2014-2020 Round of European Programmes - a Reflection Exercise, April 2012, Belfast: Department of Finance and Personnel (NI).

Department of Finance and Personnel (DFP) (1999) Northern Ireland Programme for Building Sustainable Prosperity, (Transitional Objective 1 Operational Programme), EU Structural Funds 2000-2006, Belfast: Department of Finance and Personnel (NI).

Department of Finance and Personnel (DFP) (1994) Northern Ireland Single Programming Document 1994-1999, Belfast: Department of Finance and Personnel (NI).

Department of Regional Development (DRD) (2010) 'Transport Minister visits Brussels', Press release, 24 March, available at: http://goo.gl/2ooX9q, accessed 8 August 2013.

Devine, P., G. Kelly and G. Robinson (2011) An Age of Change? Community Relations in Northern Ireland, ARK Research Update 72, Belfast: ARK.

Diez, T. and A. Wiener (2009) 'Introducing the mosaic of integration theory', in A. Wiener and T. Diez (eds) European Integration Theory (2nd edition), Oxford: Oxford University Press, pp. 1-22.

Diez, T. and K. Hayward (2008) 'Reconfiguring spaces of conflict: Northern Ireland and the impact of European integration', Space and Polity, vol. 12, no. 1, pp. 47-62.

Dinan, D. (2005) Ever Closer Union: An Introduction to European Integration (3rd edition), Basingstoke: Palgrave.

Dixon, P. (2012) 'The politics of conflict: A constructivist critique of consociational and civil society theories', Nations and Nationalism, vol. 18, no. 1, pp. 98-121.

Dixon, P. (2008) Northern Ireland: The Politics of War and Peace (2nd edition), Basingstoke: Palgrave.

Dixon, P. (2007) The Northern Ireland Peace Process: Choreography and Theatrical Politics, London: Routledge.

Dixon, P. (2006) 'Rethinking the international and Northern Ireland: A critique', in M. Cox, A. Guelke and F. Stephen (eds) A Farewell to Arms? Beyond the Good Friday Agreement 
(2nd edition), Manchester, Manchester University Press, pp. 409-426.

Dixon, P. (2002a) 'Political skills or lying and manipulation? The choreography of the Northern Ireland peace process', Political Studies, vol. 50, no. 4, pp. 725-741.

Dixon, P. (2002b) 'Northern Ireland and the international dimension: The end of the Cold War, the USA and European Integration', Irish Studies in International Affairs, vol. 13, pp. 105-120.

Donnelly, C., P. McKeown and R. Osborne (eds) (2006) Devolution and Pluralism in Education in Northern Ireland, Manchester: Manchester University Press.

Dougal, J. (2003) 'Living with press Eurotrash', British Journalism Review, vol. 14, no. 2. pp. 29-34.

Dudley Edwards, O. (1992) 'Who invented devolution?', Scottish Government Yearbook, pp. $36-48$.

Elias, A. (2008) 'Introduction: Whatever happened to the Europe of the regions? Revisiting the regional dimension of European politics', Regional and Federal Studies, vol. 15, no. 5, pp. 483-492.

Eurobarometer (2007) Attitudes towards the EU in the United Kingdom, Analytical Report, Flash EB Series no. 203, May.

European Commission (2010) Europe 2020: A Strategy for Smart, Sustainable and Inclusive Growth, Communication from the Commission, $\operatorname{COM}(2010) 2020$ final, Brussels, 3 March.

European Commission (2008) Northern Ireland Report of the Taskforce, Communication from the Commission, COM (2008) 186 final, Brussels, 7 April.

European Commission (2007) Growing Regions, Growing Europe (4th Report on Economic and Social Cohesion), Luxembourg: Office for Official Publications of the European Communities.

European Commission (1999) Northern Ireland in Europe, Belfast: European Commission Representation in Northern Ireland.

European Commission (1995) Special Support Programme for Peace and Reconciliation in Northern Ireland and the Border Counties of Ireland, Luxembourg: Office for Official Publications of the European Union.

European Commission (1994) 'Delors peace package for Northern Ireland sent to EC leaders', Press release, 7 December, available at http://goo.gl/pnmPKQ, accessed 8 August 2013.

European Commission Representation in Ireland (2010) 'Maire Geoghegan-Quinn meets Sir Reg Empey', EU News You Can Use Newsletter, Issue 272, 15 July.

European Committee (Scottish Parliament) (2001) Report on the Governance of the European Union and the Future of Europe: What Role for Scotland? (volume 1), 9th Report, SP Paper 466, December.

European External Relations Committee (Scottish Parliament) (2012) Developments in the Eurozone and their Implications for Communication between the Scottish and UK Governments, 2nd Report, SP Paper 139, May.

Eurostat (2013) 'Regional GDP per capita in the EU in 2012: Eight capital regions in the ten first places, Press release, 21 March.

Evans, G. and M. Duffy (1997) 'Beyond the sectarian divide: The social bases and political consequences of nationalist and unionist party competition in Northern Ireland', British Journal of Political Science, vol. 27, no. 1, pp. 47-81.

Farry, S. (2009) 'Consociationalism and the creation of a shared future for Northern Ireland', in R. Taylor (ed.) Consociational Theory: McGarry and O'Leary and the Northern Ireland Conflict, London: Routledge, pp. 165-179. 
Fissuh, E., O. Skarlato, S. Byrne, P. Karari and A. Kawser (2012) 'Building future coexistence or keeping people apart: The role of physical separation between communities in Northern Ireland peace process', International Journal of Conflict Management, vol. 23, no. 3, pp. 248-265.

Fitzgerald, G. (2005) 'The normalisation of the British-Irish relationship', in British Council Ireland (ed.) Britain and Ireland: Lives Entwined, Dublin: British Council Ireland, pp. 19-31.

Fitzgerald, G. (1972) Towards a New Ireland, London: Charles Knight and Co.

Gallagher, J. (2012) 'Intergovernmental relations in the UK: Cooperation, competition and constitutional change', British Journal of Politics and International Relations, vol. 14, no. 2, pp. 198-213.

Ganiel, G. (2009) "Battling in Brussels": The DUP and the European Union', Irish Political Studies, vol. 24, no. 4, pp. 575-588.

Garry, J. (2012) 'Consociationalism, regional integration and vote choice: Northern Ireland and the 2009 European Parliament election - a research note', Acta Politica, vol. 47, no. 2, pp. 113-127.

Gilbert, M. (2012) Churchill: The Power of Words, Boston: Da Capo Press.

Gilland Lutz, K. and C. Farrington (2006) 'Alternative Ulster? Political parties and the non-constitutional policy space in Northern Ireland', Political Studies, vol. 54, no. 4, pp. $715-742$.

Gillespie, P. (2000) 'Politics', in P. Gillespie (ed.) Blair's Britain, England's Europe: A view from Ireland, Dublin: Institute of European Affairs, pp. 71-103.

Goetz, K. (2008) 'Governance as a path to government', West European Politics, vol. 31, Nos $1-2$, pp. 258-279.

Gormley-Heenan, C. and P. Devine (2010) 'The "us" in trust: Who trusts Northern Ireland's political institutions and actors?', Governance and Opposition, vol. 45, no. 2, pp. 143-165.

Gormley-Heenan, C. and R. MacGinty (2009) 'Introduction: Building and breaking trust', The Roundtable: The Commonwealth Journal of International Affairs, vol. 98, no. 403, pp. 423-425.

Gudgin, G. (2000) 'EU membership and the Northern Ireland economy', in D. Kennedy (ed.) Living with the European Union: The Northern Ireland Experience, London: Macmillan, pp. 38-70.

Guelke, A. (2003) 'Civil society and the Northern Irish peace process', Voluntas: International Journal of Voluntary and Nonprofit Organisations, vol. 14, no. 1, pp. 61-78.

Guelke, A. (1988) Northern Ireland: The International Perspective, Dublin: Gill and Macmillan.

Haagerup, N.J. (1984) 'Report drawn up on behalf of the Political Affairs Committee on the situation in Northern Ireland', European Parliament Working Document, 1-1526/83, 9 March.

Haas, E.B. (1958) The Uniting of Europe: Political, Social, and Economic Forces, 1950-1957, London: Stevens.

Hadfield, B. (2001) 'Seeing it through: The multi-faceted implementation of the Belfast Agreement', in R. Wilford (ed.) Aspects of the Belfast Agreement, Oxford: Oxford University Press, pp. 84-106.

Hadfield, B. (1999) 'The nature of devolution in Scotland and Northern Ireland: Key issues of responsibility and control', Edinburgh Law Review, vol. 3, pp. 3-31.

Hainsworth, P. (1990) 'The European Community as a policy arena in Northern Ireland', in M. Connolly and S. Loughlin (eds) Public Policy in Northern Ireland: Adoption or Adaptation?, Belfast: Policy Research Institute, Queen's University Belfast, pp. 77-97. 
Hainsworth, P. (1983) 'Direct rule in Northern Ireland: The European Community dimension 1972-79', Administration, vol. 31, no. 1, pp. 53-69.

Hainsworth, P. and G. McCann (2010) 'Ringing some changes: The 2009 European election in Northern Ireland', Irish Political Studies, vol. 25, no. 2, pp. 303-314.

Hainsworth, P. and D. Morrow (1994) 'Northern Ireland: European region - European problem', Paper presented at the Political Studies Association of Ireland (PSAI) Annual Conference, Galway, October.

Harlow, C. and R. Rawlings (2007) 'Promoting accountability in multi-level governance: A network approach', European Law Journal, vol. 13, no. 4, pp. 542-562.

Hayes, B. C. and I. McAllister (2001) 'Sowing dragon's teeth: Public support for political violence and paramilitarism in Northern Ireland', Political Studies, vol. 49, no. 5, p. 901-922.

Hayward, K. (2007) 'Mediating the European ideal: Cross-border programmes and conflict resolution on the island of Ireland', Journal of Common Market Studies, vol. 45, no. 3, pp. 675-693.

Hayward, K. (2006) 'Reiterating national identities: The European Union conception of conflict resolution in Northern Ireland, Cooperation and Conflict, vol. 41, no. 3, pp. 261-284.

Hayward, K. and M. C. Murphy (2012) 'The (soft) power of commitment: The EU and conflict resolution in Northern Ireland', Ethnopolitics, vol. 11, no. 4, pp. 439-452.

Hayward, K. and M. C. Murphy (eds) (2010) The Europeanization of Party Politics in Ireland, North and South, London: Routledge.

Hepburn, E. (2009) 'The rise and fall of a "Europe of the regions", Regional and Federal Studies, vol. 18, no. 5, pp. 537-555.

HM Government (2011) Europe 2020: UK National Reform Programme 2011, London: HMSO.

HM Stationery Office (1993) Northern Ireland Structural Funds Plan, Belfast: HMSO.

HM Treasury (2011) Rebalancing the Northern Ireland Economy, Belfast: HMSO.

HM Treasury (2010) Spending Review 2010, Presented to Parliament by the Chancellor of the Exchequer, Cm 7942, October.

Hix, S. (1999) The Political System of the European Union, London: Macmillan.

Hix, S. (1998) 'The study of the European Union II: The "new governance" agenda and its rivals', Journal of European Public Policy, vol. 5, no. 1, pp. 38-65.

Hix, S. (1994) 'The study of the European Community: The challenge to comparative politics', West European Politics, vol. 17, no. 1, pp. 1-30.

Hodgett, S. and E. Meehan (2003) 'Multi-level governance in the European Union: The case of Northern Ireland', in J. M. Magone (ed.) Regional Institutions and Governance in the European Union, London: Praeger, pp. 135-151.

Hoffmann, S. (1982) 'Reflections on the nation-state in Western Europe today', Journal of Common Market Studies, vol. 21, nos 1-2, pp. 21-37.

Hoffmann, S. (1966) 'Obstinate or obsolete? The fate of the nation-state and the case of Western Europe', Daedalus, vol. 95, no. 3, pp. 862-915.

Hooghe, L. and G. Marks (2009) 'A postfunctionalist theory of European integration: From permissive consensus to constraining dissensus', British Journal of Political Science, vol. 39, no. 1, pp. 1-23.

Hooghe, L. and G. Marks (2003) 'Unravelling the central state, but how? Types of multilevel governance', American Political Science Review, vol. 97, no. 2, pp. 233-243.

Hooghe, L. and G. Marks (2001) 'Types of multi-level governance', European Integration Online Papers (EIoP), vol. 5, no. 11, pp. 1-24. 
Horgan, G. W. (2004) 'Inter-institutional relations in the devolved Great Britain: Quiet diplomacy', Regional and Federal Studies, vol. 14, no. 1, pp. 113-135.

Horgan, G. and A. M. Gray (2012) 'Devolution in Northern Ireland: A lost opportunity?', Critical Social Policy, vol. 32, no. 3, pp. 467-478.

Hume, J. (1988) 'Europe of the regions', in R. Kearney (ed.) Across the Frontiers: Ireland in the 1990s, Dublin: Wolfhound, pp. 45-57.

InterTradeIreland (2006) Comprehensive Study on the All-island Economy, Newry: InterTradeIreland.

Irish Government (2006) 'Ireland raises concerns about Sellafield at British-Irish Council Summit in London', Press release, 2 June, available at http://goo.gl/MSSCyH , accessed 8 August 2013.

Jachtenfuchs, M. (2001) 'The governance approach to European integration', Journal of Common Market Studies, vol. 39, no. 2, pp. 245-264.

Jarman, N. (2005) No Longer a Problem? Sectarian Violence in Northern Ireland, Belfast: Institute for Conflict Research (Commissioned by the Office of the First Minister and Deputy First Minister).

Jeffery, C. (2009) 'Devolution in the United Kingdom: Problems of a piecemeal approach to constitutional change', Publius: The Journal of Federalism, vol. 39, no. 2, pp. 289-313.

Jeffery, C. and D. Hough (2006) 'Devolution and electoral politics: Where does the UK fit in?', in C. Jeffery and D. Hough (eds) Devolution and Electoral Politics, Manchester: Manchester University Press, pp. 248-256.

Jeffery, C. and R. Palmer (2007) 'The European Union, devolution and power', in A. Trench (ed.) Devolution and Power in the United Kingdom, Manchester: Manchester University Press, pp. 218-238.

Jeffery, C. and D. Wincott (2006) 'Devolution in the United Kingdom: Statehood and citizenship', Publius: The Journal of Federalism, vol. 36, no. 1, pp. 3-18.

Jessop, B. (2005) 'Multi-level governance and multi-level metagovernance', in I. Bache and M. Finders (eds) Multi-level Governance, Oxford: Oxford University Press, pp. 49-74.

John, P. (2000) 'The Europeanisation of sub-national governance', Urban Studies, vol. 37, nos 5-6, pp. 877-894.

John, P. (1999) 'New Labour and the decentralisation of power', in G. Taylor (ed.) The Impact of New Labour, Basingstoke: Macmillan, pp. 120-132.

Joint Ministerial Committee (JMC) (2012) JMC Annual Report 2011-2012, available at www.scotland.gov.uk/Resource/0040/00402366.pdf, accessed 8 August 2013.

Joint Ministerial Committee (JMC) (2011) JMC Annual Report 2010-2011, available at www.northernireland.gov.uk/jmc_11_4_annual_report_final_030611.pdf, accessed 8 August 2013.

Joint Ministerial Committee (JMC) (2010) JMC Annual Report 2009-2010, available at www.ofmdfmni.gov.uk/jmcreport0910.pdf, accessed 8 August 2013.

Kearney, R. and R. Wilson (1994) 'Northern Ireland's future as a European region: Submission to the Opsahl Commission', The Irish Review, vol. 15, pp. 51-69.

Keating, M. (2008) 'Thirty years of territorial politics', West European Politics, vol. 31, nos $1-2$, pp. 60-81.

Keating, M. (2003) 'Social inclusion, devolution and policy divergence', The Political Quarterly, vol. 74, no. 4, pp. 429-438.

Keating, M. and H. Elcock (1998) 'Introduction: Devolution and the UK state', Regional and Federal Studies, vol. 8, no. 1, pp. 1-9.

Keating, M., P. Cairney and E. Hepburn (2009) 'Territorial policy communities and devolution in the UK', Journal of Regions, Economy and Society, vol. 2, no. 1, pp. 51-66. 
Kennedy, D. (ed.) (2000a) Living with the European Union: The Northern Ireland Experience, London: Macmillan.

Kennedy, D. (2000b) 'Europe and the Northern Ireland problem', in D. Kennedy (ed.) Living with the European Union: The Northern Ireland Experience, London: Macmillan, pp. $148-168$.

Kennedy, D. (2000c) 'Introduction: Portrait of a region', in D. Kennedy (ed.) (2000) Living with the European Union: The Northern Ireland Experience, London: Macmillan, pp. $1-16$.

Kennedy, D. (1994) 'The European Union and the Northern Irish question', in B. Barton and P. Roche (eds) The Northern Ireland Question: Perspectives and Policies, England: Avebury, pp. 166-188.

Kennedy, D. and M. C. Murphy (2001) 'Plus ça change: Stormont, devolution and the European Union', Paper presented to European Liaison, Queen's University Belfast, 26 June.

Knox, C. (2011) 'Cohesion, sharing and integration in Northern Ireland', Environment and Planning C: Government and Policy, vol. 29, no. 3, pp. 548-566.

Knox, C. (2009) 'The politics of local government reform in Northern Ireland', Local Government Studies, vol. 35, no. 4, pp. 435-455.

Knox, C. (1999) 'Northern Ireland: At the crossroads of political and administrative reform', Governance: An International Journal of Policy and Administration, vol. 12, no. 3, pp. 311-328.

Knox, C. and P. Carmichael (2005) 'Devolution - the Northern Ireland way: An exercise in "creative ambiguity", Environment and Planning C: Government and Policy, vol. 23, no. 1, pp. 63-83.

Kohler-Koch, B. and B. Rittberger (2006) 'Review article: The "Governance Turn" in EU studies', Journal of Common Market Studies, vol. 44, Annual Review, pp. 27-49.

Ladrech, R. (2002) 'Europeanization and political parties: Towards a framework for analysis', Party Politics, vol. 8, no. 4, pp. 389-403.

Laffan, B. (2005) 'The European context: A new political dimension in Ireland, North and South', in J. Coakley, B. Laffan and J. Todd (eds) Renovation or Revolution? New Territorial Politics in Ireland and the United Kingdom, Dublin: University College Dublin Press, pp. 166-184.

Laffan, B. and J. O'Mahony (2008) Ireland and the European Union, Basingstoke: Palgrave.

Laffan, B. and D. Payne (2001) Creating Living Institutions: Cross-border Cooperation After the Good Friday Agreement, Dublin: Institute for British-Irish Studies, University College Dublin.

Lefebvre, T. (2006) 'EU peace money: An update', Fortnight Magazine, October, pp. 4-5.

Lijphart, A. (1975) 'Review article - The Northern Ireland problem: Cases, theories and solutions', British Journal of Political Science, vol. 5, no. 1, pp. 83-106.

Lindberg, L. (1963) The Political Dynamics of European Economic Integration, London: Oxford University Press.

Little, A. (2004) Democracy and Northern Ireland: Beyond the Liberal Paradigm?, Basingstoke: Palgrave.

Lynch, P. and S. Hopkins (2001) 'The British-Irish Council: Progress frustrated', Regional Studies, vol. 35, no. 8, pp. 753-758.

MacGinty, R. and P. du Toit (2007) 'A disparity of esteem: Relative group status in Northern Ireland after the Belfast Agreement', Political Psychology, vol. 28, no. 1, pp. 13-31.

MacGiolla Chríost, D. (2000) 'The Irish language and current policy in Northern Ireland', Irish Studies Review, vol. 8, no. 1, pp. 45-55.

Magennis, E., P. Clarke and J. Shiels (2006) 'Is North-South cooperation working? Some 
lessons from border Ireland', Journal of Cross Border Studies, vol. 1, pp. 20-33.

Maguire, P. R. (1992) 'Why devolution?', in B. Hadfield (ed.) Northern Ireland: Politics and the Constitution, Buckingham: Open University Press, pp. 3-28.

Maillot, A. (2009) 'Sinn Féin's approach to the EU: Still more "critical" than "engaged"?, Irish Political Studies, vol. 24, no. 4, pp. 559-574.

Mann, M. (1993) 'Nation-states in Europe and other continents: Diversifying, developing, not dying', Daedalus, vol. 122, no. 3, pp. 115-140.

Mansergh, N. (1936) The Government of Northern Ireland: A Study in Devolution, London: George Allen and Urwin.

Marks, G. (1992) 'Structural policy in the European Community', in A. Sbragia (ed.) Europolitics: Institutions and Policy-Making in the 'New' European Community, Washington D.C.: Brookings Institution, pp. 191-224.

Marks, G. and L. Hooghe (2004) 'Contrasting visions of multi-level governance', in I. Bache and M. Flinders (eds), Multi-level Governance, Oxford: Oxford University Press, pp. $15-30$.

Marks, G., R. Haesly and H. A. D. Mbaye (2002) 'What do sub-national offices think they are doing in Brussels?', Regional and Federal Studies, vol. 12, no. 3, pp. 1-23.

Marks, G., F. Nielsen, L. Ray and S. E. Salk (1996a) 'Competencies, cracks and conflicts: Regional mobilisation in the European Union', in G. Marks et al. (eds) Governance in the European Union, London: Sage, p. 40-63.

Marks, G., L. Hooghe and K. Blank (1996b) 'European integration from the 1980s: State centric v. multi-level governance', Journal of Common Market Studies, vol. 34, no. 3, pp. 341-78.

Matthews, N. (2012) 'The Northern Ireland Assembly election 2012', Irish Political Studies, vol. 27 , no. 2 , pp. 341-358.

McAdam, N. (2009) 'Environment Minister Sammy Wilson bans adverts warning of the effects of climate change', Belfast Telegraph, 9 February.

McAleese, D. (2000) 'Twenty-five years a growing', in R. O'Donnell (ed.) Europe: The Irish Experience, Dublin: Institute of European Affairs, pp. 79-110.

McCall, C. and L. O'Dowd (2008) 'Hanging flower baskets, blowing in the wind? Third sector groups, cross-border partnerships and the EU Peace Programs in Ireland', Nationalism and Ethnic Politics, vol. 14, no. 1, pp. 29-54.

McCall, C. and A. Williamson (2001) 'Governance and democracy in Northern Ireland: The role of the voluntary and community sector after the Agreement', Governance: An International Journal of Policy, Administration and Institutions, vol. 14, no. 3, pp. 363-383.

McCall, C. and A. Williamson (2000) 'Fledgling social partnership in the Irish border region: European Union “Community Initiatives” and the voluntary sector', Policy and Politics, vol. 28. no. 3, pp. 397-410.

McCartney, R. (2000) 'The Union and the economic future of Northern Ireland', in R. English and J. Morrison Skelley (eds) Ideas Matter: Essays in Honour of Conor Cruise O’Brien, Lanham, MD: University Press of America, pp. 148-156.

McEwen, N.. W. Swenden and N. Bolleyer (2012) 'Intergovernmental relations in the UK: Continuity in a time of change?', British Journal of Political and International Relations, vol. 14 , no. 2, pp. 323-343.

McGarry, J. (2004) "Democracy" in Northern Ireland: Experiments in self-rule from the Protestant Ascendancy to the Good Friday Agreement', in J. McGarry and B. O'Leary (eds), The Northern Ireland Conflict: Consociational Engagements, Oxford: Oxford University Press, pp. 323-351. 
McGarry, J. and B. O'Leary (2009) 'Power shared after the deaths of thousands', in R. Taylor (ed.) Consociational Theory: McGarry and O'Leary and the Northern Ireland Conflict, London: Routledge, pp. 15-84.

McGarry, J. and B. O'Leary (eds) (2004) The Northern Ireland Conflict: Consociational Engagements, Oxford: Oxford University Press.

McGarry, J. and B. O'Leary (1995) Explaining Northern Ireland, Oxford: Blackwell Press.

McGarry, J. and B. O'Leary (eds) (1990) The Future of Northern Ireland, Oxford: Clarendon Press.

McGlynn, C. (2011) 'Negotiating difference in post-conflict Northern Ireland: An analysis of approaches to integrated education', Multicultural Perspectives, vol. 13, no. 1, pp. $16-22$.

McGowan, L. and M. C. Murphy (2003) 'Northern Ireland under devolution: The challenge of institutional adaptation to EU policy formulation', Regional and Federal Studies, vol. 13, no. 1, pp. 81-99.

McGowan, L. and S. O'Connor (2004) 'Exploring Eurovisions: Awareness and knowledge of the European Union in Northern Ireland', Irish Political Studies, vol. 19, no. 2, pp. 21-42.

McKee, L. (2008) 'Gildernew brings new baby to the negotiating table', Belfast Telegraph, 18 October.

McKeown, P., C. Donnelly and B. Osborne (2006) 'Conclusions', in C. Donnelly, P. McKeown and B. Osborne (eds) Devolution and Pluralism in Education in Northern Ireland, Manchester: Manchester University Press, pp. 183-187.

McKittrick, D., S. Kelters, B. Feeney, C. Thornton and D. McVea (2004) Lost Lives: The Stories of the Men, Women and Children who Died as a Result of the Northern Ireland Troubles, Edinburgh and London: Mainstream Publishing.

McLaughlin, G. and S. Baker (2012) 'The media, the peace dividend and "bread and butter" politics', The Political Quarterly, vol. 83, no. 2, pp. 292-298.

McLoughlin, P. (2009) 'The SDLP and the Europeanization of the Northern Ireland problem', Irish Political Studies, vol. 24, no. 4, pp. 603-619.

Meehan, E. (2008) 'Relations with the EU', in R. Wilford and R. Wilson (eds) Northern Ireland Devolution Monitoring Report (May), London: The Constitution Unit, UCL.

Meehan, E. (2006) 'Europe and the Europeanisation of the Irish question', in M. Cox, A. Guelke and F. Stephen (eds) A Farewell to Arms? Beyond the Good Friday Agreement (2nd edition), Manchester, Manchester University Press, pp. 338-356.

Meehan, E. (2005) 'The European context: Changing forms of territorial politics in the United Kingdom', in J. Coakley, B. Laffan and J. Todd (eds) Renovation or Revolution? New Territorial Politics in Ireland and the United Kingdom, Dublin: University College Dublin Press.

Meehan, E. (2000) “'Britain's Irish question: Britain's European question?” British-Irish relations in the context of European Union and the Belfast Agreement', Review of International Studies, vol. 26, pp. 83-97.

Meehan, E. (1999) 'The Belfast Agreement - its distinctiveness and points of cross-fertilisation in the UK's devolution programme', Parliamentary Affairs, vol. 52, no. 1, pp. 19-31.

Meehan, E. (1993) Citizenship and the European Community, London: Sage.

Michie, J. and M. Sheehan (1998) 'The political economy of a divided Ireland', Cambridge Journal of Economics, vol. 22, no. 2, pp. 243-259.

Mitchell, J. (2010) 'The Westminster model and the state of the unions', Parliamentary Affairs, vol. 63, no. 1, pp. 85-88.

Mitchell, J. (1998) 'Member-state or Euro-region?: The SNP, Plaid Cyrmu and Europe', in D. Baker and D. Seawright (eds) Britain For and Against Europe: British Politics and the 
Question of European Integration, Oxford: Oxford University Press, pp. 108-129.

Mitchell, J. and J. Bradbury (2004) 'Devolution: Comparative development and policy roles', Parliamentary Affairs, vol. 57, no. 2, pp. 329-346.

Moravcsik, A. (2008) 'The myth of Europe's “democratic deficit”, Intereconomics: Journal of European Public Policy, November-December, pp. 331-340.

Moravcsik, A. (1998) The Choice for Europe: Social Purpose and State Power from Messina to Maastricht, Ithaca, NY: Cornell University Press.

Moravcsik, A. (1993) 'Preferences and power in the European Community: A liberal intergovernmentalist approach', Journal of Common Market Studies, vol. 31, no. 4, pp. 473-524.

Moravcsik, A. (1991) 'Negotiating the Single European Act: National interests and conventional statecraft in the European Community', International Organization, vol. 45, no. 1, pp. 19-56.

Morison, J. (2006) 'Constitutionalism, civil society and democratic renewal in Northern Ireland', in M. Cox, A. Guelke and F. Stephen (eds) A Farewell to Arms? Beyond the Good Friday Agreement (2nd edition), Manchester, Manchester University Press, pp. 238-252.

Morison, J. (1999) 'Constitutionalism and change: Representation, governance, and participation in the new Northern Ireland', Fordham International Law Journal, vol. 22, no. 4, pp. $1608-1627$

Morison, J. and S. Livingstone (1995) Reshaping Public Power: Northern Ireland and the British Constitutional Crisis, London: Sweet and Maxwell.

Moxon-Browne, E. (1992) 'The impact of the European Community', in B. Hadfield (ed.) Northern Ireland: Policies and the Constitution, Buckingham: Open University Press, pp. 47-59.

Murphy, D. (1978) A Place Apart, London: Penguin Books.

Murphy, M. C. (2011) 'Regional representation in Brussels and multi-level governance: Evidence from Northern Ireland', British Journal of Politics and International Relations, vol. 13 , no. 4 , pp. 551-566.

Murphy, M. C. (2010a) 'Northern Ireland and the Republic of Ireland: A changed relationship', in J. Hogan. P. F. Donnelly and B. K. O’Rourke (eds) Irish Business and Society: Governing, Participating and Transforming in the 21st Century, Dublin: Gill and Macmillan, pp. 398-417.

Murphy, M. C. (2010b) 'The European Union and "normal" politics in Northern Ireland', in C. McCall and T. M. Wilson (eds) Europeanisation and Hibernicisation: Ireland and Europe, Amsterdam: Rodopi, pp. 173-195.

Murphy, M. C. (2009) 'Pragmatic politics: The Ulster Unionist Party and the European Union', Irish Political Studies, vol. 24, no. 4, pp. 589-602.

Murphy, M. C. (2007) 'Europeanisation and the sub-national level: Changing patterns of governance in Northern Ireland', Regional and Federal Studies, vol. 17, no. 3, pp. 293-315.

Murphy, M. C. and K. Hayward (2009) 'Party politics and the EU in Ireland, North and South', Irish Political Studies, vol. 24, no. 4, pp. 417-427.

Nolan, P. (2013) Northern Ireland Peace Monitoring Report: Ten Key Points (Report no. 2), Belfast: Community Relations Council.

Northern Ireland Assembly (2012) 'Northern Ireland's economy and labour market', Research and Information Service Research Paper NIAR 557-2012, 14 August.

Northern Ireland Assembly (2011) 'The Common Agricultural Policy - Background and Challenges Posed by Reform, Research and Information Service Briefing Paper 129/11, October.

Northern Ireland Assembly (2010) Written Ministerial Statement, Friday 26 March. 
Northern Ireland Economic Council (1992) European Community Structural Funds in Northern Ireland, Report 94, Belfast: NIEC.

Northern Ireland Executive (2012a) Programme for Government: Building a Better Future, Belfast: Stationery Office.

Northern Ireland Executive (2012b) European Priorities 2012-2013: Winning in Europe, Belfast: Stationery Office.

Northern Ireland Executive (2012c) European Priorities 2011-2012: Implementation Report, Belfast: Stationery Office.

Northern Ireland Executive (2012d) 'We can get much more money from Brussels for environment - Attwood', Press release, 9 March, available at: http://goo.gl/yxsAba, accessed 8 August 2013.

Northern Ireland Executive (2011a) Budget 2011-2015, Belfast: Stationery Office.

Northern Ireland Executive (2011b) Draft Investment Strategy for Northern Ireland 2011-2021: Building a Better Future, Belfast: Stationery Office.

Northern Ireland Executive (2011c) European Priorities 2011-2012: Winning in Europe, Belfast: Stationery Office.

Northern Ireland Executive (2010) Revised 2010-2011 Spending Plans for Northern Ireland Departments, Belfast: Stationery Office.

Northern Ireland Executive (2009) Priorities for European Engagement: Action Plan 20082009, Belfast: Stationery Office.

Northern Ireland Executive (2008a) Budget 2008-2011, Belfast: Stationery Office.

Northern Ireland Executive (2008b) Investment Strategy for Northern Ireland 2008-2018: Building a Better Future, Belfast: Stationery Office.

Northern Ireland Executive (2008c) 'Paisley and McGuinness welcome EU Taskforce report', Press release, 14 April, available at: http://goo.gl/DW2YdO, accessed 8 August 2013.

Northern Ireland Executive (2008d) Programme for Government 2008-2011, Belfast; Stationery Office.

Northern Ireland Executive (2007a) Peace III: EU Programme for Peace and Reconciliation 2007-2013 Northern Ireland and the Border Region of Ireland - Operational Programme, Belfast: Stationery Office.

Northern Ireland Executive (2007b) The European Sustainable Competitiveness Programme for Northern Ireland 2007-2013, Submitted to the European Commission, 4 October.

Northern Ireland Executive (2001) Programme for Government 2001-2004, Belfast: Office of First Minister and Deputy First Minister.

Northern Ireland Statistics and Research Agency (NISRA) (2013a) Census 2011: Detailed Characteristics for Northern Ireland on Health, Religion and National Identity (May), Belfast: NISRA.

Northern Ireland Statistics and Research Agency (NISRA) (2013b) 'Employment in the Northern Ireland civil service', Statistical Bulletin, 1 April.

Northern Ireland Statistics and Research Agency (NISRA) (2012a) Census 2011: Population and Household Estimates for Northern Ireland (July), Belfast: NISRA.

Northern Ireland Statistics and Research Agency (NISRA) (2012b) Monthly Labour Market Report (July), Belfast: NISRA.

Northern Ireland Statistics and Research Agency (NISRA) (2011) Registrar General Northern Ireland Annual Report 2008 (November), Belfast: NISRA.

Nugent, N. (2006) The Government and Politics of the European Union (6th edition), Basingstoke: Palgrave.

Office of First Minister and Deputy First Minister (OFMDFM) (2010) Programme for 
Cohesion, Sharing and Integration: Consultation Document, Belfast: OFMDFM.

Office of First Minister and Deputy First Minister (OFMDFM) (2006) Taking Our Place in Europe 2006-2010, Belfast: OFMDFM.

Office for National Statistics (2012) 'Regional gross value added (income approach)'. Statistical Bulletin, December.

O'Cleary, C. (1996) The Greening of the White House, Dublin: Gill and Macmillan.

O'Connor, F. (2009) 'Northern Ireland's new dawn', Business and Finance, 18 June, available at: www.businessandfinance.ie/index.jsp? $\mathrm{p}=161 \mathrm{and} \mathrm{n}=255 \mathrm{anda}=909$, accessed 8 August 2013.

O'Donnell, R. (1999) 'Fixing the institutions', in Democratic Dialogue No frontiers: NorthSouth Integration in Ireland, Report no. 11, pp. 70-73.

O’Dowd, L. and C. McCall (2008) 'Escaping the cage of ethno-national conflict in Northern Ireland? The importance of transitional networks', Ethnopolitics, vol. 7, no. 1, pp. 81-99.

O'Hearn, D. (2008) 'How has peace changed the Northern Irish political economy?', Ethnopolitics, vol. 7, no. 1, pp. 101-118.

O'Hearn, D. (2000) 'Peace dividend, foreign investment and economic regeneration: The Northern Irish case', Social Problems, vol. 47, no. 2, pp. 180-200.

O'Leary, B. (2002) 'The Belfast Agreement and the British-Irish Agreement: Consociation, confederal institutions, a federacy and a peace process', in A. Reynolds (ed.) The Architecture of Democracy, Oxford: Oxford University Press.

O'Leary, B. (1998) 'The nature of the Agreement', The 9th John Whyte Memorial Lecture, 26 November, Queen's University Belfast.

O'Leary, B. (1989) 'The limits to coercive consociationalism in Northern Ireland', Political Studies, vol. 37, no. 4, pp. 562-588.

O'Leary, B. and J. McGarry (1996) The Politics of Antagonism: Understanding Northern Ireland (2nd edition), London: Athlone.

Oliver, Q. (2000) 'For richer or poorer: The social impact', in D. Kennedy (ed.) Living with the European Union: The Northern Ireland Experience, London: Macmillan, pp. 115-127.

Olsen, J. P. (2008) 'EU governance: Where do we go from here?', Arena Working Paper no. 10 , May.

O’Neill, M. (2000) 'Great Britain: From Dicey to devolution', Parliamentary Affairs, vol. 53, no. 1, pp. 69-95.

O'Neill, S. (2007) 'Critical theory and ethno-national conflict: Assessing Northern Ireland's peace process as a model of conflict resolution', Irish Political Studies, vol. 22, no. 4, pp. 411-431.

Osborne, R. (2002) 'Making a difference? The role of statutory committees in the Northern Ireland Assembly', Public Administration, vol. 80, no. 2, pp. 283-299.

Papadopoulos, Y. (2010) 'Accountability and multi-level governance: More accountability, less democracy?', West European Politics, vol. 33, no. 5, pp. 1030-1049.

Paterson, O. (2012) Speech by the Rt Hon Owen Paterson MP, Co Operation Ireland Dinner, London 13 March.

Peters, B. G. and J. Pierre (2009) 'Governance approaches', in A. Wiener and T. Diez (eds) European Integration Theory (2nd edition), Oxford: Oxford University Press, pp. 91-104.

Peters, B. G. and J. Pierre (2004) 'Multi-level governance and democracy: A Faustian bargain?', in I. Bache and M. Flinders (eds) Multi-level Governance, Oxford: Oxford University Press, pp. 75-89.

Pollack, M. A. (2005) 'Theorizing EU policy-making', in H. Wallace, W. Wallace and M. A. Pollack (eds) Policy-Making in the European Union (5th edition), Oxford: Oxford University Press, pp. 13-48. 
Pricewaterhousecoopers (2004) The Impact of European Union Enlargement on the Northern Ireland Economy, Final Report for the Department of Enterprise, Trade and Investment, March.

Racioppi, L. and K. O'Sullivan See (2007) 'Grassroots peace-building and third party intervention: The European Union's Special Support Programme for Peace and Reconciliation in Northern Ireland', Peace and Change, vol. 32, no. 3, pp. 361-90.

Ramsey, P. (2013) “A pleasing blank canvas": Urban regeneration in Northern Ireland and the case of the Titanic Quarter', Space and Polity, vol. 17, no. 2, pp. 164-179.

Review of Public Administration (RPA) (2003) The Review of Public Administration in Northern Ireland, Belfast: Review of Public Administration.

Rhodes, R. A. W. (1996) 'The new governance: Governing without government', Political Studies, vol. 44, no. 3, pp. 652-667.

Robinson, P. (2011) Speech delivered at the launch of the DUP 2011 election campaign, Waterfront Hall, Belfast, 18 April, accessed online 8 August 2013.

Roper, S. (2007) 'Cross-border and local co-operation on the island of Ireland: An economic perspective', Political Geography, vol. 26, no. 5, pp. 554-574.

Rose, R. (1976) Northern Ireland: A Time of Choice, London: Macmillan.

Rowthorn, B. and N. Wayne (1988) Northern Ireland: The Political Economy of Conflict, Cambridge, Polity Press.

RTE News (2010) 'Northern Ireland Assembly Votes for Devolution', 9 March, available at: www.rte.ie/news/2010/0309/northpolitics.html, accessed 8 August 2013.

Ruane, J. and J. Todd (eds) (1999) After the Good Friday Agreement: Analysing Political Change in Northern Ireland, Dublin: University College Dublin Press.

Rutherford, A. and S. Phelan (2011) 'Wikileaks: Oversized, inefficient ... Irish verdict on Northern Ireland civil service', Belfast Telegraph, 3 June.

Scharpf, F. W. (1999) Governing in Europe, Oxford: Oxford University Press.

Scott, A. (2001) 'The role of concordats in the new Britain: Taking subsidiarity seriously?, Edinburgh Law Review, vol. 5, no. 1, pp. 21-48.

Scott, M. (2004) 'Building institutional capacity in rural Northern Ireland: The role of partnership governance in the LEADER II programme', Journal of Rural Studies, vol. 20, no. 1, pp. 49-59.

Shirlow, P. (2006) 'Segregation, ethno-sectarianism and the "new" Belfast', in M. Cox, A. Guelke and F. Stephen (eds) A Farewell to Arms? Beyond the Good Friday Agreement (2nd edition), Manchester: Manchester University Press, pp. 226-237.

Sinn Féin (2011) 'O’Neill meets EU Agriculture Commissioner to discuss CAP reform', Press release, 14 November, available at: www.sinnfein.ie/contents/21930, accessed on 8 August 2013.

Sloat, A. (2000) 'Scotland and Europe: Links between Edinburgh, London and Brussels', Scottish Affairs, vol. 31, pp. 92-110.

Smith, M. L. (2000) 'The European connection and public opinion', in D. Kennedy (ed.) Living with the European Union: The Northern Ireland Experience, Basingstoke: Palgrave, pp. 169-196.

Smyth, M. (2010) 'Northern Ireland economic outlook', First Trust Bank Economic Outlook and Business Review, vol. 25, no. 1, pp. 10-15.

Sugden, J. and A. Bairner (1993) Sport, Sectarianism and Society in a Divided Ireland, London: Leicester University Press.

Tannam, E. (2010) 'Northern Ireland and the EU: Europeanisation and hibernicisation', in C. McCall and T.M. Wilson (eds) Europeanisation and Hibernicisation: Ireland and Europe, Amsterdam: Rodopi, pp. 149-171. 
Tannam, E. (2009) 'Explaining British-Irish cooperation: The role of institutionalisation', Paper presented at the Political Studies Association (PSA) Annual Conference 2009, Manchester, 7-9 April.

Tannam, E. (2007) 'The European Commission's evolving role in conflict resolution: The case of Northern Ireland 1989-2005', Cooperation and Conflict, vol. 42, no. 3, pp. 337-356.

Tannam, E. (2006) 'Cross-border co-operation between Northern Ireland and the Republic of Ireland: Neofunctionalism revisited', British Journal of Politics and International Relations, vol. 8, no. 2, pp. 256-276.

Tannam, E. (1999) Cross-border Cooperation in the Republic of Ireland and Northern Ireland, Basingstoke: Palgrave.

Tatham, M. (2011) 'Devolution and EU policy-shaping: Bridging the gap between multilevel governance and liberal intergovernmentalism', European Political Science Review, vol. 3 , no. 1 , pp. 53-81.

Taylor, R. (2006) 'The Belfast Agreement and the politics of consociationalism: A critique', The Political Quarterly, vol. 77, no. 2, pp. 217-226.

Teague, P. (1996) 'The European Union and the Irish Peace Process', Journal of Common Market Studies, vol. 43, no. 4, pp. 549-570.

Tonge, J. (2010) 'Same old blocs, same old story? The 2010 Westminster election in Northern Ireland, Paper presented at the Annual Conference of the Political Studies Association of Ireland (PSAI), Dublin, 8-10 October.

Tonge, J. (2005a) The New Northern Irish politics?, Basingstoke: Palgrave.

Tonge, J. (2005b) 'The EU and the Irish border: Shaping aid and attitudes?', Centre for International Borders Research (CIBR), Electronic Working Papers Series 2005: www.qub. ac.uk/cibr

Tonge, J. (2002) Northern Ireland: Conflict and change (2nd edition), Essex: Pearson Education Limited.

Tonge, J. and J. Evans (2002) 'Party members and the Good Friday Agreement in Northern Ireland', Irish Political Studies, vol. 17, no. 2, pp. 59-73.

Tranholm-Mikkelsen, J. (1991) 'Neofunctionalism: Obstinate or obsolete? A reappraisal in the light of the new dynamism of the EC', Millennium, vol. 20, no. 1, pp. 1-22.

Trimble, M. (1990) 'The impact of the European Community', in R. Harris, C. Jefferson and J. Spencer (eds) The Northern Ireland Economy: A Comparative Study in the Economic Development of a Peripheral Region, London: Longman, pp. 416-439.

Turner, S. (2012) 'The strategic environmental assessment directive: A potential lever for independent environmental regulation in Northern Ireland?', Journal of Environmental Law, vol. 24, no. 2, pp. 371-384.

Turner, S. (2009) 'Devolution as a barrier to environmental reform: Assessing the response to the Review of Environmental Governance in Northern Ireland', Environmental Law Review, vol. 11, no. 3, pp. 150-160.

Turner, S. (2006) 'Transforming environmental governance in Northern Ireland. Part one: The process of policy renewal', Journal of Environmental Law, vol. 18, no. 1, pp. 55-87.

Ulster Farmers' Union (UFU) (2011) 'UFU welcomes NI Agriculture Minister to headquarters', Press release, 5 October, available at: http://goo.gl/UFNBf8, accessed 8 August 2013.

Walker, G. (2001) 'The British-Irish Council', in R. Wilford (ed.) Aspects of the Belfast Agreement, Oxford: Oxford University Press, pp. 129-141.

Wallace, H. (1999) 'Whose Europe is it anyway? The 1998 Stein Rokkan lecture', European Journal of Political Research, vol. 35, no. 3, pp. 286-306.

Wallace, H., W. Wallace and C. Webb (eds) (1977) Policy Making in the European Communi- 
ties, London: John Wiley and Sons.

Wallace, M. (1971) Northern Ireland: 50 Years of Self-Government, Newton Abbot: David and Charles.

Warleigh, A. (2006) 'Conceptual combinations: Multi-level governance and policy networks', in M. Cini and A. Bourne (eds) Palgrave Advances in European Union Studies, Basingstoke: Palgrave, pp. 77-95.

Whyte, J. (1990) Interpreting Northern Ireland Oxford: Clarendon Press.

Whyte, J. (1983) 'How much discrimination was there under the Unionist regime 19211968?', in T. Gallagher and J. O’Connell (eds) Contemporary Irish Studies, Manchester: Manchester University Press.

Wilford, R. (2010) 'Northern Ireland: The politics of constraint', Parliamentary Affairs, vol. 63 , no. 1, pp. 134-155.

Wilford, R. (2009) 'Consociational government: Inside the devolved Northern Ireland Executive', in R. Taylor (ed.) Consociational Theory: McGarry and O'Leary and the Northern Ireland Conflict, London: Routledge, pp. 180-195.

Wilford, R. (2007) 'Inside Stormont: The Assembly and the Executive', in P. Carmichael, C. Knox and R. Osborne (eds) Devolution and Constitutional Change in Northern Ireland, Manchester: Manchester University Press, pp. 167-185.

Wilford, R. (2001) 'The Assembly and the Executive: A discursive appraisal', Irish Political Studies, vol. 16, pp. 233-243.

Williamson, A., D. Scott and P. Halfpenny (2000) 'Rebuilding civil society in Northern Ireland: The community and voluntary sector's contribution to the European Union's Peace and Reconciliation District Partnership Programme', Policy and Politics, vol. 28, no. 1, pp. 49-66.

Wilson, A. J. (1995) Irish America and the Ulster Conflict 1968-1995, Belfast: Blackstaff Press.

Wilson, R. (1999) 'Public policies', in Northern Ireland Devolution Monitoring Report (Report 1), London: The Constitution Unit, UCL.

Wilson, R. (ed.) (1997). Continentally Challenged: Securing Northern Ireland's Place in the European Union, Democratic Dialogue Report no. 5, Belfast: Democratic Dialogue.

Wilson, R. and L. Fawcett (2004) The Media Election: Coverage of the 2003 Northern Ireland Assembly Poll, Belfast: Democratic Dialogue.

Wilson, T. (1989) Ulster: Conflict and Consent, Oxford: Basil Blackwell.

Wolff, S. (2005) 'Between stability and collapse: Internal and external dynamics of postAgreement institution building in Northern Ireland', in S. Noel (ed.) From PowerSharing to Democracy: Post-conflict Institutions in Ethnically Divided Societies, Montreal and Kingston: McGill-Queen's University Press, pp. 44-66.

Wolff, S. (2002) 'The peace process in Northern Ireland: Success or failure of post-Agreement reconstruction?', Civil Wars, vol. 5, no. 1, pp. 87-116.

Young, H. (1991) One of Us: A Biography of Margaret Thatcher, London: Macmillan.

\section{Newspaper sources}

'Executive criticised for failing to provide report information', BBC News Northern Ireland, 6 August 2013, available at: www.bbc.co.uk/news/uk-northern-ireland-23583785, accessed 8 August 2013.

'Full letter by Peter Robinson on the Maze', Belfast Newsletter, 15 August 2013.

'O’Neill gets positive response from Brussels', Farming Life, 21 April 2012.

'Opposition may favour the UUP', Belfast Telegraph, 20 March 2012. 
'DUP “blocks” hunger strike event', Belfast Newsletter, 24 June 2011.

\section{Official sources}

Agreement, The (1998) (Agreement reached in the multi-party negotiations), Belfast, 10 April.

Agreement at Hillsborough Castle (2010) (Hillsborough Agreement), Lisburn, 5 February. Agreement at St Andrews (2006) (St Andrews Agreement), Scotland, 11-13 October.

Irish National Development Plan (2007-2013).

Memorandum of Understanding and Supplementary Agreements (including Concordat on Coordination of European Union Policy Issues), Between the UK Government, Scottish Ministers, the Welsh Ministers and the Northern Ireland Executive Committee, March 2010 (superseding Cm. 5240).

Northern Ireland Assembly Official Reports (Hansard) 1999-2013, available at: www.niassembly.gov.uk/Assembly-Business/Official-Report/.

Northern Ireland Assembly Written Questions Database, available at: http://aims. niassembly.gov.uk/questions/writtens.aspx.

Special EU Programmes Body (SEUPB) Joint Communiqués (2000-2013), available at: http://goo.gl/EsQGke. 